UDK $577.1: 61$

ISSN 1452-8258

\title{
ASSOCIATIONS OF CHOLESTEROL AND VITAMIN D METABOLITES WITH THE RISK FOR DEVELOPMENT OF HIGH GRADE COLORECTAL CANCER
}

\section{POVEZANOST METABOLITA HOLESTEROLA I VITAMINA D SA RIZIKOM ZA NASTANAK KOLOREKTALNOG KARCINOMA VISOKOG GRADUSA}

\author{
Sandra Vladimirov1, Aleksandra Zeljkovic ${ }^{1}$, Tamara Gojkovic ${ }^{1}$, Milica Miljkovic ${ }^{1}$, Aleksandra \\ Stefanovic ${ }^{1}$, Dejan Zeljkovic ${ }^{2}$, Bratislav Trifunovic ${ }^{2,3}$, Vesna Spasojevic-Kalimanovska ${ }^{1}$ \\ ${ }^{1}$ Department of Medical Biochemistry, Faculty of Pharmacy, University of Belgrade, Belgrade, Serbia \\ ${ }^{2}$ Clinic for General Surgery, Military Medical Academy, Belgrade, Serbia \\ ${ }^{3}$ Faculty of Medicine of the Military Medical Academy, University of Defence, Belgrade, Serbia
}

\begin{abstract}
Summary
Background: Vitamin D deficiency is repeatedly reported in colorectal cancer (CRC). Since cholesterol and vitamin D share common precursor 7-dehydrocholesterol (7-DHC), it would be important to explore the associations of key vitamin D metabolites and serum lipid parameters in patients with high and low grade CRC. The aim of this study was to analyze relationships between serum 25(OH)D3, $24,25(\mathrm{OH}) 2 \mathrm{D} 3$ and 7-DHC levels and serum lipids in patients with CRC, and to evaluate their potential for prediction of risk for development of high grade CRC.

Methods: We recruited 82 patients CRC and 77 controls. 7-DHC, 25(OH)D3 and 24,25(OH)2D3 were quantified by LC-MS/MS methods.

Results: 7-DHC, 25(OH)D3 and vitamin D metabolic ratio (VDMR) were significantly lower in CRC patients than in control group $(\mathrm{P}<0.001, \mathrm{P}<0.010, \mathrm{P}<0.050$ and $\mathrm{P}<0.050$, respectively). 25(OH)D3 levels were higher in patients with grade I CRC when compared to grade II $(P<0.050)$. All vitamin $D$ metabolites positively correlated with total cholesterol (TC) concentration in CRC patients. $25(\mathrm{OH}) \mathrm{D} 3$ was significant predictor of increased CRC risk $(\mathrm{P}<0.010)$. After adjustment for TC concentration, $25(\mathrm{OH}) \mathrm{D} 3$ lost its predictive abilities. However, 25(OH)D3 remained significant predictor of poorly differentiated type of cancer $(P<0.050)$.
\end{abstract}

\section{Address for correspondence:}

Aleksandra Zeljkovic, Department of Medical Biochemistry, Faculty of Pharmacy, University of Belgrade, Vojvode Stepe 450, 11000 Belgrade, Serbia;

Phone: +381113951284

Fax: +381 113972840

e-mail: aleksandra.zeljkovic@pharmacy.bg.ac.rs

\section{Kratak sadržaj}

Uvod: Deficijencija vitamina D je učestalo javlja kod obolelih od kolorektalnog karcinoma (CRC). Kako holesterol i vitamin $D$ dele zajednički prekursor 7-dehidroholesterol (7$\mathrm{DHC})$, bilo bi značajno ispitati povezanost ključnih metabolita vitamin $D$ i serumskih lipidnih parametara kod pacijenata sa CRC klasifikovanih na osnovu gradusa. U ovom radu ispitivali smo odnos između serumskih koncentracija 25(OH)D3, 24,25(OH)2D3 and 7-DHC i serumskih lipida kod pacijenata sa CRC, kao i doprinos metabolita vitamina $\mathrm{D}$ u predikciji rizika za nastanak CRC visokog gradusa.

Metode: U studiji su učestvovala 82 pacijenta sa CRC i 77 zdravih ispitanika. 7-DHC, 25(OH)D3 i 24,25(OH)2D3 su kvantifikovani pomoću metode LC-MS/MS.

Rezultati: 7-DHC, 25(OH)D3 i odnos metabolita vitamina $D(V D M R)$ su bili značajno niži kod pacijenata sa CRC u odnosu na kontrolnu grupu $(\mathrm{P}<0,001, \mathrm{P}<0,010, \mathrm{P}<0,050$ i $\mathrm{P}<0,050$, redom). Koncentracije $25(\mathrm{OH}) \mathrm{D} 3$ su bile više kod pacijenata sa gradusom I u odnosu na pacijente sa gradusom II $(P<0,050)$. Svi metaboliti vitamina $D$ su pozitivno korelirali sa ukupnim holesterolom kod pacijenata sa CRC. 25(OH)D3 je bio značajan prediktor povećanog rizika za nastanak CRC $(P<0,010)$. Nakon korekcije za koncentraciju ukupnog holesterola, 25(OH)D3 je izgubio prediktivni značaj. Međutim, 25(OH)D3 je ostao značajan prediktor slabo diferenciranog karcinoma $(P<0,050)$.

List of abbreviations: CRC, colorectal cancer; 7-DHC, 7-dehydrocholesterol; VDMR, vitamin D metabolic ratio; DHCR7, 7$\mathrm{DHC}$-reductase; $\mathrm{BMI}$, body mass index; $\mathrm{TC}$, total cholesterol; LDL-C, low-density lipoprotein cholesterol; HDL-C, high-density lipoprotein cholesterol; TG, triglycerides; VDBP, vitamin D binding protein; MTBE, methyl-tert-buthyl ether; MRM, multiple-reaction-monitoring; $\mathrm{MMI} / \mathrm{APCl}$, multi-mode ionization/ atmospheric pressure chemical ionization; $\mathrm{OR}$, odds ratio; $\mathrm{Cl}$, confidence interval. 
Conclusions: We found significant positive association between vitamin $D$ status and serum total cholesterol. Although low 25(OH)D3 was found to be a significant risk factor for CRC development, the obtained results primarily suggest profound impact of cholesterol level on vitamin D status in CRC. However, our results suggest that low $25(\mathrm{OH}) \mathrm{D} 3$ might independently contribute to development of poorly differentiated tumor.

Keywords: 25-hydroxyvitamin D, 7-dehydrocholesterol, 24,25-dihydroxyvitamin D, total cholesterol, colorectal cancer

\section{Introduction}

Broadly recognized prevalence of vitamin $D$ deficiency in patients with colorectal cancer (CRC) directed scientific research towards the investigation of its role during the onset and progression of this malignancy. Anticancerous effects of vitamin D are well known and include induction of anti-inflammatory, anti-oxidative, anti-proliferative, anti-apoptotic and pro-differentative properties in both normal and malignant cells $(1,2)$. Yet, in spite of numerous epidemiological, clinical and interventional studies, no definitive conclusions are drawn regarding the usefulness of vitamin D treatment in CRC (3). Furthermore, a recent Mendelian randomization study has demonstrated a lack of causality between genetically determined lower levels of vitamin D and CRC risk (4), suggesting that further research should rather focus on mechanisms that can alter vitamin $\mathrm{D}$ metabolism and consequently, its effects in CRC.

Many confounding factors, including sunlight exposure, obesity, body-mass index and lipid status can affect vitamin $D$ level $(5,6)$. The relationship of vitamin $\mathrm{D}$ with serum lipids can be particularly important, considering that 7-dehydrocholesterol (7-DHC) is a direct precursor of cholesterol, but also a direct precursor of vitamin $D$ synthesis in the skin. It has been hypothesized that this metabolite and the activity of enzyme 7-DHC-reductase (DHCR7) might be critical points in determining both cholesterol and vitamin D levels (7), but this issue is insufficiently explored in CRC.

Metabolism of vitamin $D$ is complex and includes several intermediate compounds that are proposed as markers of its status in the organism. Although without biological activity, 25-hydroxyvitamin $D(25(\mathrm{OH}) \mathrm{D} 3)$ is generally accepted as a reliable marker of vitamin D status (8). However, recent evidences have emphasized 24,25-dihydroxyvitamin D $\left(24,25(\mathrm{OH})_{2} \mathrm{D} 3\right)$, a catabolic product with negligible biological activity, as a promising marker for prediction of vitamin $D$ deficiency and several associated pathological conditions (9). Accordingly, the ratio between $25(\mathrm{OH}) \mathrm{D} 3$ and $24,25(\mathrm{OH})_{2} \mathrm{D} 3$, or vitamin $\mathrm{D}$ metabolite ratio (VDMR) might provide more accurate insight into vitamin $D$ status and more precise
Zaključak: Utvrđena je značajna pozitivna korelacija između statusa vitamina D i serumskih koncentracija ukupnog holesterola. lako je uočeno da je nizak 25(OH)D3 značajan faktor rizika za razvoj $C R C$, naši rezultati upućuju na dominantan uticaj holesterola na status vitamina $\mathrm{D}$ kod ovih pacijenata. Ipak, uočeno je da niski nivoi 25(OH)D3 mogu nezavisno doprineti razvoju slabo diferentovanih oblika CRC.

Ključne reči: 25-hidroksivitamin D, 7-dehidroholesterol, 24,25-dihidroksivitamin D, ukupan holesterol, kolorektalni karcinom

prediction of possible effects of disturbed vitamin $D$ levels (10). However, there is scarce data regarding the usefulness of VDMR in CRC patients.

The goal of this study was to estimate serum $25(\mathrm{OH}) \mathrm{D} 3$ levels and concentrations of 7-DHC and $24,25(\mathrm{OH})_{2} \mathrm{D} 3$ in patients with CRC. We analyzed mutual relationship between these metabolites and evaluated their predictive abilities, as well as possible usefulness in prediction of CRC risk. Additionally, we were interested in evaluation of the associations between vitamin $D$ metabolites and markers of serum lipid status.

\section{Materials and Methods}

\section{Subjects}

For this study, we recruited 82 patients with first time diagnosed CRC. Study participants were selected from a larger cohort of 126 patients from the Clinic for General Surgery, Military Medical Academy in Belgrade, who were involved in larger research project investigating lipid status, redox balance and inflammatory markers in $\operatorname{CRC}(11,12)$. Inclusion criteria for participating in the study were: pathohistological confirmation of CRC, absence of other malignant diseases or non-malignant systemic diseases of bowel, kidney and liver, no use of hypolipidemic therapy, no use of vitamin D supplements and no use of neoadjuvant chemotherapy. After exclusion of subjects with incomplete clinical or laboratory data, the final patient's group consisted of 82 participants. Blood samples were taken immediately before surgical procedure. After an overnight fasting, blood samples were collected to EDTA plasma and serum evacuating tubes. Following the separation of serum and plasma, aliquots were frozen and stored at $-80^{\circ} \mathrm{C}$ for further analysis.

Tumor grades were defined according to pathohistological findings as: grade I (well differentiated tumor), grade II (moderately differentiated tumor) and grade III (poorly differentiated tumor). CRC grade I was diagnosed in $31.6 \%$, grade || in $53.2 \%$ and grade III in $15.2 \%$ of patients. For control group, we selected 78 healthy volunteers during their annual medical check-up examinations. All participants in control group had negative family anamnesis for CRC 
and were free of any acute or chronic disease, or use of any therapy which could affect lipid status or vitamin D levels.

Study participants were interviewed by using of standardized questionnaire. Basic information on patients' anthropometric characteristics, life style habits, use of any drugs and personal and family anamnesis were collected. Body mass index (BMI) was calculated as body weight $(\mathrm{kg}) /$ body height $\left(\mathrm{m}^{2}\right)$.

The study protocol was designed according to the ethical principles of the Helsinki Declaration. Local Ethics Committee carefully examined and approved the study. All participants were informed about the study aim and design and all of them signed an informed consent prior to the involvement.

\section{Methods}

Total proteins and components of lipid profile, including total cholesterol (TC), low-density lipoprotein cholesterol (LDL-C), high-density lipoprotein cholesterol (HDL-C) and triglycerides (TG), were determined by routine laboratory methods on ILab $300+$ automatic analyzer (Instrumentation Laboratory, Diamond Diagnostics, USA). VDBP was quantified using commercial ELISA assay for human samples, VDBP Quantikine (R\&D Systems).

\section{Vitamin D metabolites and 7-DHC analyses}

Analytical HPLC grade standards were used for quantification of the 25(OH)D3, (24R)$24,25(\mathrm{OH})_{2} \mathrm{D} 3$ (Sigma-Aldrich, St. Louis, USA). Deuterated internal standards cholesterol-26,26,26, 27,27,27-d6,25(OH)D3 3-d6 and 1,25(OH) $)_{2}$ D3 3d6 were obtained from Medical Isotopes (Pelham, USA).

$\mathrm{KOH}$ was purchased from $\mathrm{POCH}$ (Center Valley, PA, USA), while ethanol, methanol, $n$-hexane, ethylacetate, methyl-tert-buthyl ether (MTBE) and acetonitrile (HPLC grade) were obtained from Fisher (Pittsburgh, PA, USA).

The analysis of vitamin $D$ status was conducted using LC-MS/MS method developed and fully validated in our laboratory. Firstly, $500 \mathrm{~mL}$ of serum was placed in a reaction tube and $2.5 \mathrm{~mL}$ of ice cold acetonitrile were added to allow for the protein denaturation to happen. This mixture was vigorously vortexed for 30s, and centrifuged at $4000 \mathrm{xg}$ for $30 \mathrm{~min}$. The resulting supernatant was decanted into a clean reaction tube, and evaporated under nitrogen stream to the final volume of approx. $500 \mathrm{~mL}$. Afterwards, the $1 \mathrm{~mL}$ of HPLC-grade water was added, alongside with $2 \mathrm{~mL}$ of MTBE: ethylacetate mixture (9: 1, v: v). The tube was vigorously vortexed, and the upper layer was transferred into clean vial and dried under nitrogen. This extraction procedure was repeated three times in total, and all the extracts were collected in the same vial and evaporated to dryness. In the final step, the extract was reconstituted in $20 \mu \mathrm{L}$ of methanol and injected into the LC-MS/MS instrument. Chromatographic separation of $25(\mathrm{OH}) \mathrm{D} 3$ and $24,25(\mathrm{OH})_{2} \mathrm{D} 3$ and corresponding internal standards was achieved in under 20 min using Kinetex F5 $(150 \times 4.6$ mm, 2.6 $\mu \mathrm{m}, 100 \AA$ ) LC column with corresponding guard column and isocratic mobile phase methanol: water (85: $15, \mathrm{v}$ : v). Mobile phase flow was $0.3 \mathrm{~mL} / \mathrm{min}$ and column temperature $20{ }^{\circ} \mathrm{C}$. Quantification was done using multiple-reaction-monitoring (MRM) on triplequad mass spectrometer Agilent 6420 equipped with $\mathrm{MMI} / \mathrm{APCl}$ ion source. The following $\mathrm{m} / \mathrm{z}$ transitions were used for quantification of the corresponding metabolites and internal standards: 383.3115 , 105.1 for 25(OH)D3, 381.214 1.1, 105.2 for $24,25(\mathrm{OH})_{2} \mathrm{D} 3,389.37115 .2,105.3$ for $25(\mathrm{OH})$ D3-d6 and 405.37105 for 1,25(OH) $)_{2}$ D3-d6.

7-dehydrocholesterol was quantified by another LC-MS/MS method developed and validated in our laboratory. $100 \mu \mathrm{L}$ was mixed with internal standard and $1 \mathrm{~mL}$ of $2 \%$ potassium hydroxide in ethanol, vortexed and incubated for $30 \mathrm{~min}$ at $45^{\circ} \mathrm{C}$. Afterwards, $500 \mu \mathrm{L}$ of water was added and $2 \mathrm{~mL}$ of $\mathrm{n}$-hexane. After vortexing and centrifugation (1500xg for 5 $\min )$, organic layer was separated. After collecting and combining three organic layers into one reaction tube, the extract was dried under nitrogen. Prior the analysis, the extract was reconstituted in $100 \mu \mathrm{L}$ of methanol. Poroshell 120 EC-C18 column $(4.6 \times 150$ $\mathrm{mm}, 2.7 \mu \mathrm{m}$ ) with corresponding guard column, and isocratic mobile phase containing acetonitrile: methanol: water (80: 18: 2, v: v: v) were used for chromatographic separation. 7-dehydrocholesterol and internal standard were eluted in 30 min runtime. The following $\mathrm{m} / \mathrm{z}$ transitions were used for quantification of the 7-DHC and cholesterol-26,26,26,27,27,27-d6: $367.3131 .3,105.3$ and 375.3 105.2, 95.2, respectively. Quantification was done using multiple-reaction-monitoring (MRM) on triple quad mass spectrometer Agilent 6420 equipped with $\mathrm{MMI} / \mathrm{APCl}$ ion source.

\section{Statistical analysis}

Normality of data was tested by the ShapiroWilk test. Normally distributed variables are presented as means \pm standard deviation, while asymmetrically distributed data as median (interquartile range). Categorical data are presented as absolute frequencies and analyzed by the Chi-square test. For comparison of continuous data with normal and asymmetrical distribution were used Student t-test and Mann-Whitney U-test, respectively. Comparison of data stratified according to tumor grades was performed by Kruskal-Wallis test. Correlation analysis was performed by using Spearman correlation coefficients. Univariate logistic regression was employed for detection of significant predictors of CRC develop- 
ment and tumor grade. Adjustment in multivariate logistic regression analysis was made for age, gender and BMI (Model 1) and for age, gender, BMI and TC level (Model 2). For statistical analysis we used IBM $\AA$ SPSS ${ }^{\circ}$ model 22.0. Differences were considered significant if $P<0.05$.

\section{Results}

General characteristics of the examined groups are presented in Table I. Patients were older than controls. Nevertheless, there were no significant correlations between age and $25(\mathrm{OH}) \mathrm{D} 3,24,25(\mathrm{OH})_{2} \mathrm{D} 3,7-$ DHC, VDMR, VDBP in control group $(\rho=-0.051$, $P=0.659 ; \rho=0.016, P=0.891 ; \rho=-0.056, P=0.632$; $\rho=-0.099, P=0.390 ; \rho=-0.172, P=0.197$, respectively) nor in the patient group $(\rho=-0.162, P=0.152$; $\rho=-0.184, \quad P=0.102 ; \quad \rho=-0.135, \quad P=0.233 ; \rho=-$ $0.111, P=0.326 ; \rho=-0.155, P=0.230$, respectively). Additionally, we divided both cohorts (patients and controls) into quartiles according to age and also found no statistically significant differences in all of the vitamin D-related parameters between these quartiles (data not shown). Male sex was more prevalent in the CRC group. BMI and total proteins concentrations were significantly lower in CRC patients. Our results demonstrated a significant decrease in TC, LDL-C and HDL-C concentrations in patients with $\mathrm{CRC}$ when compared to healthy individuals. Levels of TG were comparable among the groups.
Next we analyzed differences in markers of vitamin D status. Concentrations of 7-DHC were lower in CRC patients, as well as levels of $25(\mathrm{OH}) \mathrm{D} 3$. In addition, the patients had lower levels of VDBP. We did not find significant differences, although we recorded lower levels of 24,25(OH) 2 D3 in CRC group. Finally, values of VDMR were decreased in patients (Table I).

In order to check the influence of seasonal variations and exposure to UV light on markers of vitamin D status, we divided both patients and controls in two subgroups, according to the season when blood samples were collected (winter season from November to April, or summer season from May to October). The results are presented in Table $I I$. None of the examined markers in patients differed with respect to season when samples are taken. On the other hand, in the control group we found significantly higher concentrations of $25(\mathrm{OH}) \mathrm{D} 3$ and $24,25(\mathrm{OH})_{2} \mathrm{D} 3$ in subjects who were included in study during the season with higher exposure to UV light.

Analysis of vitamin D status parameters in patients with different tumor grades (Table III) demonstrated a decrease in concentrations of $25(\mathrm{OH}) \mathrm{D} 3$ alongside with the increase of tumor grade, with statistical significance reached between grade I and grade II. In contrast, concentration of $24,25(\mathrm{OH}) 2 \mathrm{D} 3$ was significantly higher in subjects with tumor grade II when compared to patients with well differentiated tumors. We found no significant differences in TC concentration among patients with tumor grades I-III.

Table I General characteristics and parameters of vitamin D status in study groups.

\begin{tabular}{|c|c|c|c|}
\hline Parameter & CRC patients $(N=82)$ & Controls $(\mathrm{N}=77)$ & $P$ \\
\hline Age (years)* & $64.51 \pm 10.89$ & $54.09 \pm 7.73$ & $<0.001$ \\
\hline Gender (male/female)\# & $58 / 24$ & $44 / 33$ & 0.098 \\
\hline BMI $\left(\mathrm{kg} / \mathrm{m}^{2}\right)^{*}$ & $25.20 \pm 3.28$ & $26.35 \pm 3.72$ & 0.030 \\
\hline Total protein $(\mathrm{g} / \mathrm{L})^{*}$ & $65.87 \pm 6.91$ & $73.40 \pm 6.95$ & $<0.001$ \\
\hline $\mathrm{TC}(\mathrm{mmol} / \mathrm{L})$ & $4.43(3.68-4.97)$ & $5.62(4.63-6.38)$ & $<0.001$ \\
\hline LDL-C (mmol/L) & $2.81(2.13-3.20)$ & $3.64(2.88-4.33)$ & $<0.001$ \\
\hline HDL-C (mmol/L) & $0.99(0.79-1.18)$ & $1.23(0.95-1.53)$ & $<0.001$ \\
\hline TG $(\mathrm{mmol} / \mathrm{L})$ & $1.22(0.99-1.43)$ & $1.31(1.04-1.68)$ & 0.316 \\
\hline 7-DHC ( $\mu \mathrm{mol} / \mathrm{L})$ & $1.24(0.91-1.94)$ & $1.75(1.23-2.56)$ & 0.002 \\
\hline $25(\mathrm{OH}) \mathrm{D} 3(\mathrm{ng} / \mathrm{mL})$ & $15.93(12.04-22.18)$ & $18.98(15.85-23.75)$ & 0.003 \\
\hline $24,25(\mathrm{OH})_{2} \mathrm{D} 3(\mathrm{ng} / \mathrm{mL})$ & $2.98(2.54-3.62)$ & $3.26(2.70-4.00)$ & 0.135 \\
\hline VDMR & $5.12(4.49-6.17)$ & $5.55(4.84-6.66)$ & 0.016 \\
\hline $\operatorname{VDBP}(\mu \mathrm{g} / \mathrm{mL})$ & $265.66(210.45-332.68)$ & $300.56(258.12-342.88)$ & 0.030 \\
\hline
\end{tabular}

Values are presented as median (interquartile range) and compared by the Mann-Whitney U-test.

*Values are presented as mean \pm standard deviation and compared by the Student t-test.

\#Values are presented as absolute frequencies and compared by the Chi-square test. 
Table II Seasonal effects on parameters of vitamin D status.

\begin{tabular}{|l|c|c|c|c|c|c|}
\hline \multirow{2}{*}{ Parameter } & \multicolumn{2}{|c|}{ CRC patients } & $P$ & \multicolumn{2}{c|}{ Controls } & \multicolumn{2}{|c|}{$\begin{array}{c}\text { Winter season } \\
(\mathrm{N}=54)\end{array}$} \\
\cline { 2 - 6 } & $\begin{array}{c}\text { Summer season } \\
(\mathrm{N}=48)\end{array}$ & $\begin{array}{c}\text { Winter season } \\
(\mathrm{N}=34)\end{array}$ & & $\begin{array}{c}\text { Summer season } \\
(\mathrm{N}=23)\end{array}$ & $1.90(1.39-2.79)$ & 0.125 \\
\hline $7-\mathrm{DHC}(\mu \mathrm{mol} / \mathrm{L})$ & $1.28(0.47-2.13)$ & $1.24(0.91-1.93)$ & 0.918 & $1.61(1.05-2.27)$ & $18.33(15.04-22.28)$ & 0.023 \\
\hline $25(\mathrm{OH}) \mathrm{D3}(\mathrm{ng} / \mathrm{mL})$ & $16.13(12.41-22.92)$ & $15.98(10.61-21.66)$ & 0.618 & $22.54(16.37-31.40)$ & $18.15(2.62-3.74)$ & 0.005 \\
\hline $\begin{array}{l}24,25(\mathrm{OH}) 2 \mathrm{D} 3 \\
(\mathrm{ng} / \mathrm{mL})\end{array}$ & $3.13(2.61-4.26)$ & $2.84(2.61-3.67)$ & 0.408 & $3.55(3.04-5.38)$ & 3.15 \\
\hline VDMR & $5.12(4.52-6.10)$ & $5.09(4.41-6.36)$ & 0.925 & $5.53(4.83-6.63)$ & $5.70(4.90-6.76)$ & 0.738 \\
\hline VDBP $(\mu \mathrm{g} / \mathrm{mL})$ & $266.94(220.45-340.80)$ & $260.13(246.49-336.02)$ & 0.797 & $334.28(232.42-389.63)$ & $296.60(259.86-334.28)$ & 0.352 \\
\hline
\end{tabular}

Values are presented as median (interquartile range) and compared by the Mann-Whitney U-test.

Table III TC and parameters of vitamin D status according to CRC grade.

\begin{tabular}{|l|c|c|c|c|}
\hline Parameter & Grade I & Grade II & Grade III & $P$ \\
\hline TC $(\mathrm{mmol} / \mathrm{L})$ & $4.23(3.44-5.23)$ & $4.34(3.75-4.80)$ & $4.48(3.65-5.03)$ & 0.705 \\
\hline 7-DHC $(\mu \mathrm{mol} / \mathrm{L})$ & $1.25(1.06-2.14)$ & $1.23(0.94-1.81)$ & $0.79(0.79-1.81)$ & 0.563 \\
\hline $25(\mathrm{OH}) \mathrm{D3}(\mathrm{ng} / \mathrm{mL})$ & $19.66(15.74-25.06)$ & $14.77(10.31-19.09) \mathrm{a}^{* *}$ & $14.27(11.96-18.90)$ & $<0.050$ \\
\hline $24,25-(\mathrm{OH})_{2} \mathrm{D3}(\mathrm{ng} / \mathrm{mL})$ & $3.11(2.76-4.20)$ & $3.18(2.50-3.45) \mathrm{a}^{*}$ & $2.93(2.61-3.86)$ & $<0.050$ \\
\hline VDMR & $5.68(4.66-7.18)$ & $4.78(3.90-5.60)$ & $4.74(4.46-5.20)$ & 0.143 \\
\hline VDBP $(\mu \mathrm{g} / \mathrm{mL})$ & $266.94(223.11-361.62)$ & $260.13(197.57-302.90)$ & $306.51(208.21-366.40)$ & 0.380 \\
\hline
\end{tabular}

Values are presented as median (interquartile range) and compared by the Kruskal-Wallis test and post hoc Mann-Whitney test. a - significantly different from Grade I

${ }^{*} \mathrm{P}<0.050 ;{ }^{*} \mathrm{P}<0.01$.

Table IV Changes in parameters of vitamin D status according to TC concentration in CRC patients.

\begin{tabular}{|l|c|c|c|}
\hline Parameter & $\begin{array}{c}\mathrm{TC}<4.43 \\
\mathrm{mmol} / \mathrm{L}\end{array}$ & $\begin{array}{c}\mathrm{TC}>4.43 \\
\mathrm{mmol} / \mathrm{L}\end{array}$ & $P$ \\
\hline $\begin{array}{l}7-\mathrm{DHC} \\
(\mu \mathrm{mol} / \mathrm{L})\end{array}$ & $\begin{array}{c}1.08 \\
(0.77-1.52)\end{array}$ & $\begin{array}{c}1.47 \\
(1.01-2.33)\end{array}$ & 0.014 \\
\hline $\begin{array}{l}25(\mathrm{OH}) \mathrm{D} 3 \\
(\mathrm{ng} / \mathrm{mL})\end{array}$ & $\begin{array}{c}15.67 \\
(10.07-16.68)\end{array}$ & $\begin{array}{c}17.23 \\
(12.21-24.90)\end{array}$ & 0.020 \\
\hline $\begin{array}{l}24,25(\mathrm{OH}) 2 \mathrm{D} 3 \\
(\mathrm{ng} / \mathrm{mL})\end{array}$ & $\begin{array}{c}2.82 \\
(2.44-3.44)\end{array}$ & $\begin{array}{c}3.36 \\
(2.69-3.93)\end{array}$ & 0.006 \\
\hline VDMR & $\begin{array}{c}4.94 \\
(4.50-5.58)\end{array}$ & $\begin{array}{c}4.98 \\
(4.43-6.77)\end{array}$ & 0.636 \\
\hline VDBP $(\mu \mathrm{g} / \mathrm{mL})$ & $\begin{array}{c}263.11 \\
(209.07-326.94)\end{array}$ & $\begin{array}{c}269.06 \\
(210.77-343.53)\end{array}$ & 0.741 \\
\hline
\end{tabular}

Values are presented as median (interquartile range) and compared by the Mann-Whitney U-test.

In the next step, we explored correlations of vitamin D status markers with other determined parameters. Spearman correlation analysis did not revealed any significant correlations between vitamin $D$ status markers and anthropometric measures or protein lev- els (data not shown). Regarding relationship with serum lipid levels, we found significant positive correlations between TC concentration and levels of 7DHC $(\rho=0.347 ; P<0.01), 25(\mathrm{OH}) \mathrm{D3} \quad(\rho=0.245$; $P<0.05)$ and 24,25(OH) 2 D3 $(\rho=0.295 ; P<0.01)$ in CRC patients. In addition, significant positive correlation was observed between LDL-C and 7-DHC $(\rho=0.293 ; \quad P<0.01)$ and $25(\mathrm{OH}) \mathrm{D} 3 \quad(\rho=0.238$; $\mathrm{P}<0.05)$. Regarding the control group, positive association of TG concentration with 7-DHC was recorded $(\rho=0.331 ; P<0.01)$.

To further explore the observed associations of TC with markers of vitamin D status, we stratified CRC patients according to median values of TC concentrations. The results of comparison of vitamin $D$ status markers between the two groups of patients with different TC levels are presented in Table $I V$. We observed significantly higher levels of 7-DHC, $25(\mathrm{OH}) \mathrm{D} 3$ and $24,25(\mathrm{OH})_{2} \mathrm{D} 3$ in a group of CRC patients with higher concentrations of TC. On the other hand, values of VDMR and VDBP did not significantly differ among groups.

Finally, we examined a capacity of explored vitamin D metabolites and VDBP for possible use as 
Table V Logistic regression analysis for evaluation of parameters of vitamin D status in prediction of risk for CRC development.

\begin{tabular}{|c|c|c|c|}
\hline \multicolumn{4}{|c|}{ Univariate logistic regression } \\
\hline Parameter & OR & $95 \% \mathrm{Cl}(\mathrm{OR})$ & $P$ \\
\hline 7-DHC ( $\mu \mathrm{mol} / \mathrm{L})$ & 0.926 & $(0.762-1.124)$ & 0.437 \\
\hline 25(OH)D3 (ng/mL) & 0.934 & $(0.892-0.979)$ & 0.004 \\
\hline $24,25(\mathrm{OH})_{2} \mathrm{D} 3$ & 0.701 & $(0.514-0.956)$ & 0.025 \\
\hline VDMR & 0.769 & $(0.604-0.980)$ & 0.034 \\
\hline $\operatorname{VDBP}(\mu \mathrm{g} / \mathrm{mL})$ & 0.997 & $(0.993-1.001)$ & 0.115 \\
\hline \multicolumn{4}{|c|}{ Multivariate logistic regression } \\
\hline \multicolumn{4}{|l|}{ Model 1} \\
\hline Parameter & OR & $95 \% \mathrm{Cl}(\mathrm{OR})$ & $P$ \\
\hline 25(OH)D3 (ng/mL) & 0.943 & $(0.893-0.996)$ & 0.035 \\
\hline $24,25(\mathrm{OH})_{2} \mathrm{D} 3$ & 0.714 & $(0.498-1.025)$ & 0.068 \\
\hline VDMR & 0.837 & $(0.613-1.144)$ & 0.264 \\
\hline \multicolumn{4}{|l|}{ Model 2} \\
\hline Parameter & OR & $95 \% \mathrm{Cl}(\mathrm{OR})$ & $P$ \\
\hline 25(OH)D3 (ng/mL) & 0.967 & $(0.912-1.025)$ & 0.263 \\
\hline $24,25(\mathrm{OH})_{2} \mathrm{D3}$ & 0.807 & $(0.558-1.168)$ & 0.256 \\
\hline VDMR & 0.936 & $(0.669-1.310)$ & 0.701 \\
\hline
\end{tabular}

Model 1: adjustment was made for age, gender $(\mathrm{m} / \mathrm{f})$ and BMI. Model 2: adjustment was made for age, gender $(\mathrm{m} / \mathrm{f}), \mathrm{BMI}$ and TC.

Table VI Parameters of vitamin D status in prediction of high grade tumor development.

\begin{tabular}{|c|c|c|c|}
\hline \multicolumn{4}{|c|}{ Univariate logistic regression } \\
\hline Parameter & OR & $95 \% \mathrm{Cl}(\mathrm{OR})$ & $P$ \\
\hline 7-DHC ( $\mu \mathrm{mol} / \mathrm{L})$ & 1.040 & $(0.811-1.334)$ & 0.756 \\
\hline $25(\mathrm{OH}) \mathrm{D} 3(\mathrm{ng} / \mathrm{mL})$ & 0.911 & $(0.845-0.983)$ & $<0.05$ \\
\hline $24,25(\mathrm{OH})_{2} \mathrm{D} 3$ & 0.548 & $(0.301-0.999)$ & 0.050 \\
\hline VDMR & 0.734 & $(0.527-1.023)$ & 0.068 \\
\hline $\operatorname{VDBP}(\mu \mathrm{g} / \mathrm{mL})$ & 0.997 & $(0.992-1.002)$ & 0.281 \\
\hline \multicolumn{4}{|c|}{ Multivariate logistic regression } \\
\hline \multicolumn{4}{|l|}{ Model 1} \\
\hline Parameter & OR & $95 \% \mathrm{Cl}(\mathrm{OR})$ & $P$ \\
\hline 25(OH)D3 (ng/mL) & 0.895 & $(0.822-0.975)$ & $<0.050$ \\
\hline \multicolumn{4}{|l|}{ Model 2} \\
\hline Parameter & OR & $95 \% \mathrm{Cl}(\mathrm{OR})$ & $P$ \\
\hline 25(OH)D3 (ng/mL) & 0.898 & $(0.823-0.979)$ & $<0.050$ \\
\hline
\end{tabular}

Model 1: adjustment was made for age, gender $(\mathrm{m} / \mathrm{f})$ and BMI. Model 2: adjustment was made for age, gender $(\mathrm{m} / \mathrm{f}), \mathrm{BMI}$ and TC. markers of $\mathrm{CRC}$ risk prediction (Table $\mathrm{V}$ ). Univariate logistic regression analysis revealed that low levels of $25(\mathrm{OH}) \mathrm{D3}, 24,25(\mathrm{OH})_{2} \mathrm{D} 3$ and VDMR have significant potential for prediction of CRC development, while $25(\mathrm{OH}) \mathrm{D} 3$ retained its significance after the adjustment for traditional risk factors (age, male sex and $\mathrm{BMI}$ ). However, after the inclusion of TC concentration in the Model 2, 25(OH)D3 lost its predictive potential. On the other hand, TC concentration was recognized as potential significant predictor of CRC in combination with traditional risk factors and 25(OH)D3 (OR: 0.417; Cl: 0.267-0.650; $\mathrm{P}<0.001)$, 24,25(OH) 2 D3 (OR: 0.409; Cl: 0.262-0.637; $\mathrm{P}<0.001)$, and VDMR (OR: 0.404; $\mathrm{Cl}: 0.259-0.629$; $\mathrm{P}<0.001$ ).

Similar analysis was performed to explore potential of vitamin D status parameters in prediction of tumor grade. Patients are stratified in two cohorts: subjects with low grade tumor (grade I) and subjects with high grade tumor (grade II + grade III). Our results (Table VI) demonstrated that only 25(OH)D3 was a significant risk factor for high grade carcinoma development. In contrast to previous analysis, the observed significance retained after adjustment for other cofounders (age, male sex and BMI) and even after inclusion of TC in the model.

\section{Discussion}

In this study, we demonstrated that concentrations of 7-DHC, 25(OH)D3 and VDMR were decreased in CRC patients. 25(OH)D3 emerged as the most prominent marker of changed vitamin $D$ status in CRC patients, as well as the molecule with the highest potential for prediction of CRC development. However, its predictive potential was abolished when TC, as a routine lipid status marker, was included in the analysis.

It is well known that status of vitamin D is diminished in patients with CRC (3). Our results (Table I) support these findings. We observed a decrease in concentrations of 7-DHC, 25(OH)D3 and VDBP, but no differences between patients and controls were recorded for $24,25(\mathrm{OH})_{2} \mathrm{D} 3$ (Table I). It is widely accepted that seasonal variations in sun exposure are major contributors to the vitamin D status (13), which was also confirmed by the results in our healthy cohort (Table II). However, when we analyzed vitamin $D$ metabolites in CRC patients, we did not find any differences that could be attributed to the seasonal variations in sun exposure. Therefore, our results suggest that lower vitamin D status in CRC patients is more likely a consequence of processes related to the disease itself, than a result of reduced sun exposure.

Metabolic processing of vitamin $D$ is complex and not solely limited to liver and kidney. Instead, extrarenal tissues, including colon, are active sites of vitamin D metabolism (14). Namely, it has been 
demonstrated that both CYP27B1, an enzyme responsible for synthesis of active vitamin $D$ form, and CYP24A1, responsible for synthesis of inactive 24,25(OH)2D3 metabolite, are present in colonocytes and regulated by the level of cell's differentiation (14). Since previous researches confirmed enhanced activity of CYP24A1 in less differentiated colon cancer cells $(14,15)$, it would be expectable to find increased concentrations of $24,25(\mathrm{OH})_{2} \mathrm{D} 3$ in systemic circulation of CRC patients. However, our results did not show any differences in $24,25(\mathrm{OH})_{2}$ D3 serum levels between patients and controls (Table I). Yet, it is important to notice that evidences regarding increased CYP24A1 and $24,25(\mathrm{OH})_{2} \mathrm{D} 3$ are derived from studies on cancer tissue and cells, but not from analyses in serum. Since blood levels of vitamin D metabolites are a reflection of metabolic processes in numerous tissues, but principally in liver and kidney, the influence of altered metabolism in cancer cells might not be sufficient to change serum concentration of a particular metabolite. However, eventual broad use of vitamin D metabolites for prediction and prognosis of CRC development would likely be oriented toward serum or plasma samples. Our results (Table I) suggest that $24,25(\mathrm{OH})_{2}$ D3 might not be a reliable marker for these purposes. In addition, although $24,25(\mathrm{OH})_{2} \mathrm{D} 3$, alongside with 7-DHC were recognized as independent predictors of CRC in an univariate analysis, adjustment for age, gender and BMI abolished their prognostic capacity (Table V), thereby confirming the above mentioned presumption. On the other hand, VDMR was significantly lower in patients (Table I), but such finding most likely reflected the presence of significant differences in 25(OH)D3 concentrations, thus emphasizing the importance of this vitamin $D$ metabolite.

It has been shown that vitamin D metabolism in malignant cells is influenced by the extracellular availability of its active form and subsequent interaction with vitamin D receptors (16). Also, previous studies have demonstrated that the activity of CYP27B1 and CYP24A1 depends on availability of substrate $25(\mathrm{OH}) \mathrm{D} 3(17,18)$. Accordingly, overall amount of $25(\mathrm{OH}) \mathrm{D} 3$ is responsible for local activation and effects of vitamin D. In our study, serum 25(OH)D3 and 7-DHC were significantly lower in CRC patients (Table I), thereby setting prerequisites for later defective vitamin $D$ activation and biological function in extrarenal tissues. In parallel with low levels of vitamin $D$ precursors, we also observed a decrease in TC, LDL-C and HDL-C levels (Table I). These findings could be of particular importance, since vitamin $D$ and cholesterol share a common precursor: 7-DHC. Previous studies of serum lipid levels in CRC are inconsistent, but the findings similar to ours were reported in the study of Abaza et al. (19). Apart from poor nutritional status frequently seen in CRC (20), which could be one of the reasons for decreased cho- lesterol synthesis in the liver, it has been recently proposed that reprogramming of lipid metabolism could be responsible for the observed decrease in serum lipid status markers in various types of cancer (20, 21). Namely, it has been demonstrated that cancer cells extensively accumulate and use cholesterol (22, 23), while such increased needs are satisfied by either upregulated endogenous synthesis (24), or enhanced uptake of circulating cholesterol $(25,26)$. Such rearrangement of cholesterol synthesis and cellular accumulation could have important consequences regarding vitamin $D$ status. It has been proposed that 7-DHC is placed in the center of metabolic shift between cholesterol and vitamin $D$ synthesis pathways (7). In our study, lower levels of 7-DHC were recorded in CRC patients (Table I). Thus, it is possible that in conditions of increased utilization of cholesterol by malignant cells and consequent generalized direction of biosynthesis towards cholesterol, vitamin D synthesis is compromised. In confirming such assumption, we observed strong positive correlation of serum levels of TC, LDL-C and HDL-C with 7-DHC and analyzed vitamin D3 metabolites, but only in a group of CRC patients. These findings suggest that decreased serum cholesterol levels, which are indicative for increased cholesterol utilization by malignant cells, are associated with diminished vitamin D synthesis and further metabolic transformation. Previously, Bogh et al. (26) have demonstrated that elevation of 25(OH)D3 level after sun exposure was in positive correlation with TC concentration. Thus, local production of vitamin $D$ in the skin can also be compromised in the conditions of decreased serum TC in CRC. Due to generalized lack of circulating cholesterol, as seen in CRC, and consequent disabled uptake by the other body structures apart from malignant tissue, it would be reasonable to expect that biosynthesis pathways in keratinocytes would likely be directed towards cholesterol, rather than towards vitamin D. Taken all together, our results might indicate that decreased levels of vitamin $D$, regularly seen in CRC, are in the first place a consequence of disturbed lipid profile. Indeed, when we divided CRC patients according to TC concentrations (Table IV), we found lower values of 7-DHC, 25(OH)D3 and even $24,25(\mathrm{OH})_{2} \mathrm{D} 3$ in subjects with low TC, thereby confirming the impact of circulating cholesterol on all aspects of vitamin D metabolism.

Finally, when we explored independent potential of vitamin $\mathrm{D}$ metabolites in predicting the risk for CRC development (Table V), serum levels of 25(OH)D3 emerged as the most potent marker, whose relevance was retained even after the adjustment for wellknown contributors of CRC development. However, inclusion of TC concentration to the designed model, eliminated the independent impact of decreased $25(\mathrm{OH}) \mathrm{D} 3$ on CRC development, which is in line with the postulated role of $\mathrm{TC}$ in directing of vitamin $\mathrm{D}$ metabolism. Interestingly, low serum TC was recog- 
nized as an independent predictor of CRC, emphasizing the role of lipid alterations in etiopathogenesis of this disease. The role of lipids in cancer development was neglected for a long time, but recent research shed light on this topic (20). We have previously demonstrated changed activity of lipid transfer proteins (11) and alterations of lipoprotein subclasses (12) in CRC patients. Possible influence on vitamin D metabolites demonstrated herein can present an additional effect of disturbed lipid homeostasis during the development and progression of CRC.

Nevertheless, the role of vitamin D itself on the tumor progression cannot be neglected. Namely, we found a decrease in serum 25(OH)D3 levels across tumor grades in parallel with an increase in $24,25(\mathrm{OH})_{2} \mathrm{D} 3$ in grade II CRC (Table III). The lack of significant differences during comparison of grade III subgroup with other subjects is most likely a consequence of smaller number of participants in this group. It is well known that vitamin D enhances cell differentiation $(1,2)$, so the observed decrease of $25(\mathrm{OH}) \mathrm{D} 3$ in patients with poorly differentiated cancer is expected. More importantly, low 25(OH)D3 level was revealed as independent predictor of high grade CRC, even after adjustment for other risk factors, including TC concentration (Table VI). Therefore, our results suggest that $25(\mathrm{OH}) \mathrm{D} 3$ could be useful as potential serum marker of increased risk for high grade CRC, which should be further explored in future studies. Data about the association between vitamin D and tumor grade in CRC are scarce. Yet, it has been recently demonstrated that expression of nuclear vitamin D receptors gradually decreases during the progression of low grade adenoma towards high grade adenoma and CRC (27). Our findings regarding serum vitamin $D$ levels are in agreement with these results. It also should be noticed that determination of serum $25(\mathrm{OH}) \mathrm{D} 3$ is a simple and inexpensive procedure, implying that vitamin $D$ might be considered as easily available and potentially useful indicator of tumor grade in CRC patients.

It should also be mentioned that we observed significantly lower VDBP levels in CRC patients when compared to healthy participants (Table I). Such results were expectable since VDBP is primarily synthesized by the liver and it is well documented that tumor-associated inflammation and production of cytokines can decrease hepatic protein synthesis, while on the other hand, malignant cells can increasingly uptake serum proteins (28). Altogether, these processes result in decreased total serum protein which was also seen in our study (Table I). However, our results did not demonstrate significant independ- ent contribution of VDBP to the modulation of risk for CRC development (Table $V$ ), which is in line with previous researches $(28,29)$, thus suggesting that the impact of VDBP during CRC progression is more likely indirect and related to vitamin $\mathrm{D}$.

Several limitations should be emphasized. Due to increased prevalence of CRC in older subjects and limited possibilities to involve a sufficient number of elderly healthy volunteers, patients and controls were not completely matched by age. Although older age is recognized as a significant contributor to lower vitamin D status, in this study we found no differences in vitamin $D$ metabolites among different age groups. However, our results should be further evaluated in groups of patients and controls matched by age.

Patients and controls could not be matched entirely by age for the purpose of this study. Additionally, since this is an observational study, we could not fully explore the presumed causality between decreased TC level and minimized vitamin D synthesis. Future researches for verifying our hypothesis and elucidating possible mechanisms of these interactions are needed. Next, cross-sectional nature of our study prevented us from drawing conclusions regarding the role of observed associations during the progression of CRC. Forthcoming prospective studies should address this topic.

\section{Conclusions}

In conclusion, our results demonstrated decreased levels of 7-DHC, 25(OH)D3 and VDMR in patients with CRC. In addition, we observed a significant positive association between vitamin $D$ status and serum lipid markers. Although $25(\mathrm{OH}) \mathrm{D} 3$ was revealed as significant marker of CRC development, the obtained results suggested profound impact of serum cholesterol on the levels of vitamin D metabolites and give a new perspective for understanding the vitamin $\mathrm{D}$ deficiency in $\mathrm{CRC}$, and possible improvement of patient management strategies.

Funding: This study was financially supported by a grant from the Ministry of Education, Science and Technological Development, Republic of Serbia (Project No. 175035).

\section{Conflict of interest statement}

The authors state that they have no conflicts of interest regarding the publication of this article. 


\section{References}

1. Jeon SM, Shin EA. Exploring vitamin D metabolism and function in cancer. Exp Mol Med 2018; 50: 20.

2. Merchan BB, Morcillo S, Martin-Nunez G, Tinahones FJ, Macías-González M. The role of vitamin $D$ and VDR in carcinogenesis: through epidemiology and basic sciences. J Steroid Biochem Mol Biol 2017; 167: 203-18.

3. Dou R, Ng K, Giovannucci EL, Manson JE, Qian ZR, Ogino S. Vitamin D and colorectal cancer: molecular, epidemiological and clinical evidence. Br J Nutr 2016; 115: $1643-60$

4. He $Y$, Timofeeva M, Farrington SM, Vaughan-Shaw $P$ Svinti $V$, Walker $M$, et al. Exploring causality in the association between circulating 25-hydroxyvitamin D and colorectal cancer risk: a large Mendelian randomisation study. BMC Med 2018; 16: 142.

5. Vallès $\mathrm{X}$, Alonso MH, López-Caleya JF, Díez-Obrero $\mathrm{V}$, Dierssen-Sotos T, Lope $\mathrm{V}$, et al. Colorectal cancer, sun exposure and dietary vitamin $D$ and calcium intake in the MCC-Spain study. Environ Int 2018; 121: 428-34.

6. Vekic J, Zeljkovic A, Stefanovic A, Jelic-Ivanovic Z, Spasojevic-Kalimanovska V. Obesity and dyslipidemia. Metabolism 2019; 92: 71-81.

7. Prabhu AV, Luu W, Li D, Sharpe $\sqcup$, Brown AJ. DHCR7: A vital enzyme switch between cholesterol and vitamin $D$ production. Prog Lipid Res 2016; 64: 138-51.

8. Dirks $N$, Ackermans $M$, Lips $P$, de Jongh $R$, Vervloet $M$, de Jonge $R$, et al. The when, what \& how of measuring vitamin $D$ metabolism in clinical medicine. Nutrients 2018; 10: 482

9. Kaufmann M, Gallagher JC, Peacock M, Schlingmann KP, Konrad M, DeLuca HF, et al. Clinical utility of simultaneous quantitation of 25-hydroxyvitamin D and 24, 25-dihydroxyvitamin D by LC-MS/MS involving derivatization with DMEQ-TAD. J Clin Endocrinol Metab 2014; 99: 2567-74.

10. Fabregat-Cabello N, Farre-Segura J, Huyghebaert L, Peeters S, Le Goff C, Souberbielle JC, et al. A fast and simple method for simultaneous measurements of 25 $(\mathrm{OH}) \mathrm{D}, 24,25(\mathrm{OH}) 2 \mathrm{D}$ and the vitamin D metabolite ratio (VMR) in serum samples by LC-MS/MS. Clin Chim Acta 2017; 473: 116-23.

11. Mihajlovic $M$, Gojkovic T, Vladimirov $S$, Miljkovic $M$, Stefanovic A, Vekic J, et al. Changes in lecithin: cholesterol acyltransferase, cholesteryl ester transfer protein and paraoxonase-1 activities in patients with colorectal cancer. Clin Biochem 2019; 63: 32-8.

12. Stevanovic M, Vekic J, Bogavac-Stanojevic N, Janac J, Stjepanovic Z, Zeljkovic D, et al. Significance of LDL and $\mathrm{HDL}$ subclasses characterization in the assessment of risk for colorectal cancer development. Biochem Med 2018; 28: $503-13$

13. Holick MF. Sunlight, ultraviolet radiation, vitamin D and skin cancer: how much sunlight do we need? Adv Exp Med Biol 2014; 810: 1-16.

14. Cross HS, Bises G, Lechner D, Manhardt T, Kállay E. The Vitamin $D$ endocrine system of the gut-its possible role in colorectal cancer prevention. J Steroid Biochem Mol Biol 2005; 97: 121-8.
15. Sun $H$, Jiang $C$, Cong $L$, Wu N, Wang $X$, Hao $M$, et al. CYP24A1 Inhibition Facilitates the Antiproliferative Effect of 1, $25(\mathrm{OH})$ 2D3 Through Downregulation of the WNT/ $\beta$-Catenin Pathway and Methylation-Mediated Regulation of CYP24A1 in Colorectal Cancer Cells. DNA Cell Biol 2018; 37: 742-9.

16. Peterlik M, Cross HS. Dysfunction of the vitamin D endocrine system as common cause for multiple malignant and other chronic diseases. Anticancer Res 2006; 26: 2581-8.

17. Adams JS, Chen H, Chun R, Ren S, Wu S, Gacad M, et al. Substrate and enzyme trafficking as a means of regulating 1,25-dihydroxyvitamin D synthesis and action: the human innate immune response. J Bone Miner Res 2007; 22: V20-4.

18. Abaza H, Ghanem A, Jmal A, Harzallah L, Rahal K, Guemira F. Changes in serum lipids in patients with colorectal cancer. Tunis Med 2011; 89: 147-50.

19. Ziętarska M, Krawczyk-Lipiec J, Kraj L, Zaucha R, Małgorzewicz S. Nutritional statusassessment in colorectal cancer patients qualified to systemic treatment. Contemp Oncol (Pozn.) 2017; 21: 157.

20. Cruz PM, Mo H, McConathy W, Sabnis NA, Lacko AG The role of cholesterol metabolism and cholesterol transport in carcinogenesis: a review of scientific findings, relevant to future cancer therapeutics. Frontiers Pharmacol 2013; 4: 119.

21. Tirinato $L$, Liberale $C$, Di Franco S, Candeloro P, Benfante A, La Rocca R, et al. Lipid droplets: a new player in colorectal cancer stem cells unveiled by spectroscopic imaging. Stem Cells 2015; 33: 35-44.

22. Murai T. The role of lipid rafts in cancer cell adhesion and migration. Int J Cell Biol 2012; 2012: 763283.

23. Sharon C, Baranwal S, Patel NJ, Rodriguez-Agudo D, Pandak WM, Majumdar AP, et al. Inhibition of insulin-like growth factor receptor/AKT/mammalian target of rapamycin axis targets colorectal cancer stem cells by attenuating mevalonate-isoprenoid pathway in vitro and in vivo. Oncotarget 2015; 6: 15332.

24. Aguirre-Portolés C, Feliu J, Reglero G, Ramírez de Molina A. ABCA1 overexpression worsens colorectal cancer prognosis by facilitating tumour growth and caveolin-1dependent invasiveness, and these effects can be ameliorated using the BET inhibitor apabetalone. Mol Oncol 2018; 12: 1735-52.

25. Uda S, Accossu S, Spolitu S, Collu M, Angius F, Sanna F, et al. A lipoprotein source of cholesteryl esters is essential for proliferation of CEM-CCRF lymphoblastic cell line. Tumour Biol 2012; 33: 443-53.

26. Bogh MK, Schmedes AV, Philipsen PA, Thieden E, Wulf HC. Vitamin D production after UVB exposure depends on baseline vitamin $D$ and total cholesterol but not on skin pigmentation. J Invest Dermat 2010; 130: 546-53.

27. Šutalo N, Tomić S, Bevanda M, Dragišić V, Marijanović I, Petričević J, et al. Immunohystochemical Expression of Vitamin D Receptor in Development Stages of Colorectal Carcinoma. Psychiatr Danub 2017; 29(Suppl 4): 855-8. 
28. Andersen SW, Shu XO, Cai Q, Khankari NK, Steinwandel $M D$, Jurutka PW, et al. Total and Free Circulating Vitamin $D$ and Vitamin D-Binding Protein in Relation to Colorectal Cancer Risk in a Prospective Study of African Americans. Cancer Epidemiol Biomarkers Prev 2017; 26: 1242-7.
29. Song M, Konijeti GG, Yuan C, Ananthakrishnan AN, Ogino S, Fuchs CS, et al. Plasma 25-hydroxyvitamin D, vitamin $\mathrm{D}$ binding protein, and risk of colorectal cancer in the Nurses' Health Study. Cancer Prev Res (Phila) 2016; 9: 664-72. 